\title{
Geographic variation in ectoparasitic mites diversity in Tadarida brasiliensis (Chiroptera, Molossidae)
}

\author{
Tatiana C. Pesenti ${ }^{1}$, Sâmara N. Gomes ${ }^{1}$, Ana M. Rui ${ }^{2} \&$ Gertrud Müller ${ }^{1}$
}

\footnotetext{
1. Laboratório de Parasitologia de Animais Silvestres, Departamento de Microbiologia e Parasitologia, Instituto de Biologia, Universidade Federal de Pelotas, Pelotas, Rio Grande do Sul, Brazil. (tatianapesenti@yahoo.com.br)

2. Laboratório de Ecologia de Aves e Mamíferos, Departamento de Ecologia, Zoologia e Genética, Instituto de Biologia, Universidade Federal de Pelotas, Pelotas, Rio Grande do Sul, Brazil.
}

\begin{abstract}
Tadarida brasiliensis (Geoffroy, 1824), the Brazilian free-tailed bat, is an insectivorous bat that occurs from southern United States of America to southern South America. In this study we present the first data on diversity of ectoparasitic mites of T. brasiliensis in Brazil. A compilation and analysis of the studies of mite diversity conducted in different points the geographic distribution this bat species are provided. The mites were collected from March 2010 to November 2011 on 160 T. brasiliensis adult bats captured in southern Brazil. Four species of mites have been found: Chiroptonyssus robustipes (Ewing, 1925), Ewingana longa (Ewing, 1938), Ewingana inaequalis (Radford, 1948), and specimens of Cheyletidae. Chiroptonyssus robustipes was the most prevalent species (100\%), followed by E. longa (20\%), E. inaequalis (10\%), and specimens of Cheyletidae (1.25\%). The data currently available show that C. robustipes parasitizes $T$. brasiliensis throughout its region of occurrence, and this mite is highly prevalent and abundant. The two species of Ewingana accompany the geographical distribution of $T$. brasiliensis, but with much lower prevalence and abundance.
\end{abstract}

KEYWORDS. Brazilian free-tailed bat, Acari, Macronyssidae, Myobiidae, Cheyletidae.

RESUMO. Variação geográfica na diversidade de ácaros ectoparasitos em Tadarida brasiliensis (Chiroptera, Molossidae). Tadarida brasiliensis (Geoffroy, 1824) é um morcego insetívoro que ocorre desde o sul dos Estados Unidos até o sul da América do Sul. Neste estudo são apresentados os primeiros dados sobre diversidade de ácaros ectoparasitos de T. brasiliensis no Brasil e é disponibilizada uma compilação e análise dos estudos de diversidade de ácaros realizados nos diferentes pontos da distribuição geográfica desta espécie de morcego. Os ácaros foram coletados de 160 espécimes adultos de T. brasiliensis capturados no extremo sul do Brasil, entre março de 2010 e novembro de 2011. Quatro espécies de ácaros foram coletadas: Chiroptonyssus robustipes (Ewing, 1925), Ewingana longa (Ewing, 1938), Ewingana inaequalis (Radford, 1948) e espécimes de Cheyletidae. Chiroptonyssus robustipes foi a espécie mais prevalente (100\%), seguido de E. longa (20\%), E. inaequalis (10\%) e exemplares de Cheyletidae (1,25\%). Os dados disponíveis atualmente demonstram que C. robustipes parasita T. brasiliensis em toda sua região de ocorrência e que este ácaro é altamente prevalente e abundante. As duas espécies de Ewingana acompanham a distribuição geográfica de T. brasiliensis, porém com prevalências e abundâncias muito menores.

PALAVRAS-CHAVE. Morcego brasileiro da cauda livre, Acari, Macronyssidae, Myobiidae, Cheyletidae.

Tadarida brasiliensis (Geoffroy, 1824), the Brazilian free-tailed bat, is an insectivorous bat of the family Molossidae with a wide geographic distribution, occurring from Southern United States of America (USA), through Mexico, Central America, and western South America to about $45^{\circ} \mathrm{S}$ including Brazil, Uruguay, Chile, and Argentina. It also occurs in the Small and Great Antilles in the Caribbean (WiLkins, 1989; Simmons, 2005). In Brazil, it occurs mainly in the southeast and south regions, where the temperatures are lower. Tadarida brasiliensis form colonies in several kinds of shelters including caves, sewers, attics, bridges, and tree hollows (WILKINS, 1989).

Tadarida brasiliensis was well studied in the USA, however there is little information on this species out of North America (WILKINS, 1989). Regarding acarine ectoparasites of $T$. brasiliensis, most studies were conducted in the southern USA; however, few contain information for a significant number of individuals. Among the studies conducted with a great number of hosts include: DURDEN et al. (1992) and Ritzi et al. (2001), in USA, with 133 and 96 specimens, respectively; GuZMÁn-CoRNEJo et al. (2003), in Mexico, with 98 specimens; and MuÑoz et al. (2011), in Chile, with 195 specimens. Few studies were conducted in South America, and only two (MuÑoz et al., $2003,2011)$ are comprehensive studies of ectoparasites of T. brasiliensis; however, only MuÑoz et al. (2003) report the parasitic indexes found. The other studies are records of occurrence of Acari species (YUNKER \& RADOVSKY, 1966; SAunders, 1975; Mauri, 1982). There is no information concerning mite parasites in T. brasiliensis from Brazil.

The knowledge of the ectoparasite fauna of bats can provide important information on behavior and biological aspects of its host (FrITZ, 1983). In this study we present the first data on mite ectoparasites of T. brasiliensis in Brazil, and we include data on the species richness, and parameters of prevalence, mean abundance and mean intensity. We also provide a compilation of the studies on mite ectoparasites of $T$. brasiliensis throughout its geographic distribution to discuss the existence of geographic variation in diversity, to detect gaps in knowledge on the subject, and priority approaches for future studies.

\section{MATERIAL AND METHODS}

From March 2010 to November 2011, 160 adult specimens ( 80 males and 80 females) of T. brasiliensis 
from a colony housed in the attic of a one-story masonry building in the Municipality of Capão do Leão (31 ${ }^{\circ} 48^{\prime}$ '03'S; $\left.52^{\circ} 24^{\prime} 29^{\prime \prime} \mathrm{W}\right)$, state of Rio Grande do Sul, Brazil, were captured in a harp trap.

Bats were anesthetized with ketamine hydrochloride by injection intramuscular (considering the weight and volume) and after euthanized in $\mathrm{CO}_{2}$ chamber (licenced by ICMBio). Then were individually packed in plastic bags, and maintained under refrigeration for a few days in the laboratory until the time of analyses. Three different procedures were performed for collecting the ectoparasites: the body surfaces of the bats were examined under a stereomicroscope, the pelage was brushed on a tray with white background, and the bats were washed for thirty minutes in a vessel containing approximately $400 \mathrm{~mL}$ of water and $3 \mathrm{~mL}$ of detergent. The material that remained in the tray and water resulting from washing were examined under a stereomicroscope to obtain the ectoparasites. All mites were clarified in lacto phenol and mounted on slides for counting and identification. Some of these specimens were mounted on permanent slides in Hoyer's Solution.

Mite identification was made according to keys of Ewing (1938), Fonseca (1948), DusbáBek (1968), and KRANTZ (1978). Parameters of prevalence (frequency of parasitized hosts in a sample), mean abundance (mean of the number of individuals of a particular parasite species per host examined) and mean intensity (mean of the number of individuals of a particular parasite species per infested host in a sample) of the mites were calculated according to Bush et al. (1997). The specimens were deposited in the Arthropod Collection of the Laboratory of Wild Animals Parasitology, Institute of Biology, Universidade Federal de Pelotas (UFPel), Pelotas (RS), Brazil.

We performed an extensive literature review to exhaust the location of new articles. The following information was summarized: study site, number of hosts analyzed, species found, species richness, and parasitic indexes.

\section{RESULTS AND DISCUSSION}

A total of 4,837 mites of four species were collected from 160 specimens of $T$. brasiliensis: 4,751 Chiroptonyssus robustipes (Ewing, 1925) (Macronyssidae) (Figs 1, 2), 63 Ewingana longa (Ewing, 1938) (Myobiidae) (Figs 3, 4), 21 Ewingana inaequalis (Radford, 1948) (Myobiidae) (Fig. 5), and two specimens of Cheyletidae (Fig. 6) (Tab. I).

Thirteen different species, eight genera and two families (Tab. II) were identified in the 18 studies compiled on mite parasites of $T$. brasiliensis. The richness varied from one species, obtained in several studies, to nine species in the cave of Cueva de La Boca, in Mexico (GuzMánCoRnejo et al., 2003). Considering only the most temporally comprehensive studies and those that analyzed a number of individuals, apparently the greatest richness of mites occurs in populations of T. brasiliensis from southeastern USA (Foster \& Mertins, 1996), and in Mexico (GuZMÁNCoRnejo et al., 2003). However, here are no data for most species distributed in South America, including southern and southeastern Brazil, regions that should be studied. The richness of mites found in this study may be considered low, and is similar to those obtained by DURDEN et al. (1992), SpeArs et al. (1999), Ritzi et al. (2001), and MuÑoz et al. (2011); however, it is lower than the richness obtained in the studies conducted by Foster \& Mertins (1996) and GuZMÁn-Cornejo et al. (2003) (Tab. II).

Chiroptonyssus robustipes was the most abundant and prevalent in the present study, being found in $100 \%$ of the bats (Tab. I). This result agrees with the studies in the U.S.A by Foster \& Mertins (1996) and McAllister et al. (2006); in Chile by MuÑoz et al. (2003); and in Mexico by GuZMÁn-CoRnejo et al. (2003) who also found 100\% prevalence. High prevalence was also reported by DURDEN et al. (1992) and RITZI et al. (2001), USA, which obtained amounts of $86.87 \%$ and $83.33 \%$, respectively (Tab. II).

Chiroptonyssus robustipes parasitizes T. brasiliensis throughout its geographic distribution, from the USA to southern Brazil, Argentina and Chile (Tab. II). Tadarida brasiliensis is the typical host and almost exclusive for C. robustipes, although this species of mite also occurs in other bats species such as Myotis nigricans (Schinz, 1821), M. californicus Audubon and Bachman, 1842, Eptesicus fuscus (Beauvois, 1796), and Nyctinomops macrotis (Gray, 1839), however, with lower mean intensity (DURDEN et al., 1992; GuZMÁN-CoRnEJo et al., 2003). In Brazil, there are records of this mite parasitizing $N$. macrotis and other unidentified species in state of São Paulo (FonsECA, 1948); however, there are no reports of this mite infesting $T$. brasiliensis in Brazil.

Two species of Ewingana were found in this study. Ewingana longa had a prevalence of $20 \%$ (Tab. I). In USA, low prevalence in T. brasiliensis was reported by DURDEN et al. (1992), Foster \& Mertins (1996), and Ritzi et al. (2001), of $1 \%, 3.5 \%$ and $11.46 \%$, respectively. However, GuZmán-CorneJo et al. (2003), in Mexico, recorded high prevalences $(42 \%, 50 \%, 63 \%$, and 68\%) (Tab. II). Ewingana

Tab. I. Parameter of infestation by mites in Tadarida brasiliensis (Geoffroy, 1824) captured from 2010 to 2011 in Rio Grande do Sul State, Brazil $(n=160)$.

\begin{tabular}{|c|c|c|c|c|c|}
\hline Mites & No. collected & Infestation range & Prevalence (\%) & $\begin{array}{c}\text { Mean } \\
\text { Intensity } \pm \text { SD }\end{array}$ & $\begin{array}{c}\text { Mean } \\
\text { Abundance } \pm \mathrm{SD}\end{array}$ \\
\hline Chiroptonyssus robustipes & 4751 & $1-204$ & 100 & $29.69 \pm 24.67$ & $29.69 \pm 24.67$ \\
\hline Ewingana longa & 63 & $0-8$ & 20 & $1.96 \pm 1.75$ & $0.39 \pm 1.1$ \\
\hline Ewingana inaequalis & 21 & $0-2$ & 10 & $1.31 \pm 0.47$ & $0.13 \pm 0.42$ \\
\hline Cheyletidae & 2 & $0-1$ & 1.25 & 1 & $0.012 \pm 0.11$ \\
\hline
\end{tabular}




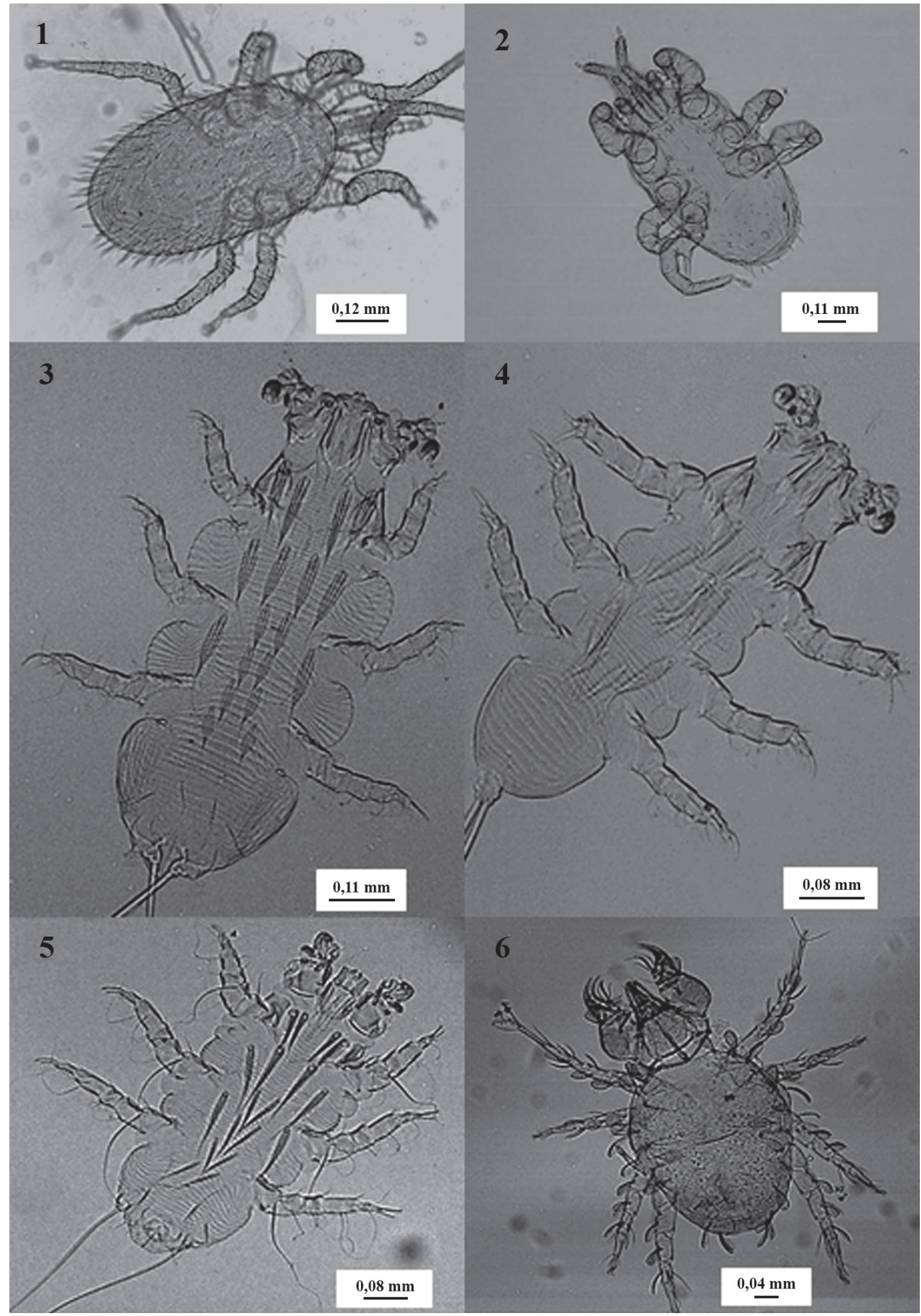

Figs 1-6, ectoparasitc mites of Tadarida brasiliensis (Geoffroy, 1824). Chyroptonyssus robustipes (Ewing, 1925): 1, dorsal view; 2, ventral view. Ewingana longa (Ewing, 1938), dorsal view: 3, female; 4, male. 5, Ewingana inaequalis (Radford, 1948), dorsal view of female. 6, dorsal view of Cheyletidae. 
Tab. II. Studies on mites ectoparasites of Tadarida brasiliensis (Geoffroy, 1824) at different regions. List of species collected and their parasitic indexes [P (\%)*, prevalence; MI*, mean intensity; MA*, mean abundance; NA, not available].

\begin{tabular}{|c|c|c|c|c|}
\hline \multirow{2}{*}{ Reference } & \multirow{2}{*}{$\begin{array}{c}\text { No bats } \\
\text { examinated }\end{array}$} & \multirow{2}{*}{ Location } & \multirow{2}{*}{ Mites } & Parasitic Index \\
\hline & & & & $\mathrm{P}(\%)^{*} \quad \mathrm{MI}^{*} \quad \mathrm{MA}^{*}$ \\
\hline
\end{tabular}

\begin{tabular}{lcc}
\hline BRADSHAW \& Ross, 1961 & NA & Arizona (EUA) \\
DuRDEN et al., 1992 & $133 \quad$ Alabama (EUA)
\end{tabular}

SPEARS et al., 1999

McAllister et al., 2006

JAMESON, 1959

STRANDTMann, 1962
WhitaKer \& EAsterla, 1975

RITZI et al., 2001

Foster \& Mertins, 1996

DusBÁBEK \& CRUZ, 1966

DUSBÁBEK, 1968

GuZMÁN-CORNEJo et al., 2003

GuZmÁn-CoRnejo et al., 2003

GuZMÁN-CoRnEJo et al., 2003

$\begin{array}{ll}10 & \text { Arkansas (EUA) } \\ 55 & \text { Texas (EUA) }\end{array}$

NA Texas (EUA)

NA Texas (EUA)

96 Texas (EUA)

$45 \quad$ Florida (EUA)
Chiroptonyssus robustipes

Steatonyssus sp.

Chiroptonyssus robustipes

Steatonyssus ceratognathus (Ewing, 1923)

Steatonyssus occidentalis (Ewing, 1933)

Ewingana longa

Androlaelaps casalis (Berlese, 1887)

Chiroptonyssus robustipes

Steatonyssus ceratognathus

Cheletonella vespertilionis (Womersley, 1941)

Teinocoptes sp.

Nycteriglyphus sp.

Chiroptonyssus robustipes

Chiroptonyssus robustipes

Ewingana longa

Trombicula sp.

Nycteriglyphus bifolium (Strandtmann, 1962)

Chiroptonyssus robustipes

Steatonyssus occidentalis

Chiroptonyssus robustipes

Ewingana longa

Trombiculidae

Chiroptonyssus robustipes

Dentocarpus macrotrichus Dusbábek \& Cruz, 1966

Ewingana inaequalis

Ewingana longa

Ewingana sp.

Notoedres sp.

Raphignathus sp.

Cheyletidae

Dentocarpus macrotrichus

Ewingana inaequalis

Chiroptonyssus robustipes

Macronyssus unidens (Radovsky, 1967)

Ewingana inaequalis

Ewingana Longa

Leptotrombidium mexicana Wharton \& Fuller, 1952

Whartonia (Asolentria) sp.

Dentocarpus macrotrichus

Notoedres lasionycteris (Boyd, 1950)

12 Río Salado (Mexico)

Chiroptonyssus robustipes

Ewingana inaequalis

Ewingana longa

Whartonia (Asolentria) sp.

Dentocarpus macrotrichus

Notoedres lasionycteris

Olabidocarpus nyctinomus Fain, 1976

Chiroptonyssus robustipes

Ewingana inaequalis

Ewingana longa

Leptotrombidium mexicana

Dentocarpus macrotrichus

Notoedres (Notoedres) sp.

Notoedres lasionycteris

\begin{tabular}{|c|c|c|}
\hline - & - & - \\
\hline- & - & - \\
\hline 86.8 & 8.4 & - \\
\hline 6 & 1.9 & - \\
\hline 2 & 1 & - \\
\hline 1 & 1 & - \\
\hline 1 & 5 & - \\
\hline 98 & - & - \\
\hline- & - & - \\
\hline- & - & - \\
\hline- & - & - \\
\hline- & - & - \\
\hline 100 & - & - \\
\hline- & - & - \\
\hline- & - & - \\
\hline- & - & - \\
\hline- & - & - \\
\hline- & - & - \\
\hline- & - & - \\
\hline 83.3 & - & 6.75 \\
\hline 11.4 & - & 0.32 \\
\hline 1.04 & - & 0.03 \\
\hline 100 & - & - \\
\hline 3.5 & - & - \\
\hline 3.5 & - & - \\
\hline 3.5 & - & - \\
\hline 3.5 & - & - \\
\hline 3.5 & - & - \\
\hline 3.5 & - & - \\
\hline 3.5 & - & - \\
\hline- & - & - \\
\hline- & - & - \\
\hline 100 & - & 39.8 \\
\hline 3.2 & - & 0.03 \\
\hline 26 & - & 0.5 \\
\hline 42 & - & 1.03 \\
\hline 13 & - & 0.5 \\
\hline 3.2 & - & 0.4 \\
\hline 3.2 & - & 0.03 \\
\hline 25.8 & - & 0.74 \\
\hline 100 & - & 95.5 \\
\hline 58.3 & - & 1.6 \\
\hline 50 & - & 1.75 \\
\hline 41.7 & - & 4 \\
\hline 25 & - & 8.9 \\
\hline 58.3 & - & 2.91 \\
\hline 16.6 & - & 15 \\
\hline 100 & - & 39.1 \\
\hline 33.3 & - & 1.1 \\
\hline 63 & - & 2 \\
\hline 15 & - & 1 \\
\hline 14.8 & - & 0.3 \\
\hline 7.4 & - & 0.1 \\
\hline 51.8 & - & 2.5 \\
\hline
\end{tabular}




\begin{tabular}{|c|c|c|c|c|c|c|}
\hline \multirow{2}{*}{ Reference } & \multirow{2}{*}{$\begin{array}{c}\text { No bats } \\
\text { examinated }\end{array}$} & \multirow{2}{*}{ Location } & \multirow{2}{*}{ Mites } & \multicolumn{3}{|c|}{ Parasitic Index } \\
\hline & & & & $\mathrm{P}(\%)^{*}$ & MI* & $\mathrm{MA}^{*}$ \\
\hline \multirow{8}{*}{ GuZMÁN-CORNEJo et al., 2003} & \multirow{8}{*}{28} & \multirow{8}{*}{$\begin{array}{l}\text { Concepción del Oro } \\
\text { (Mexico) }\end{array}$} & Olabidocarpus nyctinomus & 29.6 & - & 5.07 \\
\hline & & & Chiroptonyssus robustipes & 100 & - & 186.2 \\
\hline & & & Ewingana inaequalis & 57.1 & - & 2 \\
\hline & & & Ewingana longa & 68 & - & 2 \\
\hline & & & Leptotrombidium mexicana & 8 & - & 0.2 \\
\hline & & & Whartonia sp. & 3.6 & - & 0.03 \\
\hline & & & Dentocarpus macrotrichus & 3.7 & - & 0.5 \\
\hline & & & Notoedres lasionycteris & 21.7 & - & 0.25 \\
\hline PENCE et al., 1981 & 2 & $\begin{array}{l}\text { Antillean island } \\
\text { (Dominica) }\end{array}$ & Chiroptonyssus robustipes & - & - & - \\
\hline SAUNDERS, 1975 & NA & Mérida (Venezuela) & Chiroptonyssus robustipes & - & - & - \\
\hline YUNKER \& RADOVSKY, 1966 & NA & $\begin{array}{l}\text { Cerro Punta } \\
\text { (Panamá) }\end{array}$ & Chiroptonyssus robustipes & - & - & - \\
\hline \multirow[t]{3}{*}{ MuÑOz et al., 2003} & 90 & Concepción (Chile) & Chiroptonyssus robustipes & 100 & - & - \\
\hline & & & Ewingana inaequalis & 32.2 & - & - \\
\hline & & & Notoedres lasionycteris & 40 & - & - \\
\hline \multirow[t]{3}{*}{ MuÑoz et al., 2011} & 195 & Santiago (Chile) & Chiroptonyssus robustipes & - & - & - \\
\hline & & & Ewingana inaequalis & - & - & - \\
\hline & & & Notoedres lasionycteris & - & - & - \\
\hline MAURI, 1982 & NA & La Plata (Argentina) & Chiroptonyssus robustipes & - & - & - \\
\hline
\end{tabular}

inaequalis showed a prevalence of $10 \%$ (Tab. I), higher than that recorded by Foster \& MERTins (1996) in USA (3.5\%), however lower than those reported by MuÑoz et al. (2003) in Chile (32.22\%) and GuZMÁn-CORNEJo et al. (2003) in Mexico (26\%, 33.3\%, 57.1\%, and 58.3\%) (Tab. II). There are no reports of occurrence of these mites in Brazil or infestation by these mites in other bat species.

Mites of Myobiidae show high specificity, and many species are specific to a single host genus (FaIN, 1994). Ewingana longa and E. inaequalis probably infest T. brasiliensis throughout its geographic distribution (Tab. II). The compiled data indicate that $E$. inaequalis is present in T. brasiliensis populations, from the USA (DuRDEN et al., 1992; Foster \& Mertins 1996) to Chile (MuÑoz et al., 2003; MuÑoz et al., 2011), and in southern Brazil (this study), and $E$. longa occurs in populations from the USA (JAMESON, 1959; Durden et al., 1992; Foster \& Mertins, 1996; Ritzi et al., 2001), Mexico (GuZMÁn-CoRnejo et al., 2003), and southern Brazil (this study).

The low prevalence of Cheyletidae obtained (Tab. I) is similar to that reported by Foster \& MERTins (1996) (3.5\%) in USA (Tab. II). In this country, SPEARS et al. (1999) reported the occurrence of Cheletonella vespertilionis (Womersley, 1941) in T. brasiliensis. Most species of Cheyletidae are free-living predators preying on other arthropods, including mites; however, some species can parasitize small mammals, among them bats (EzequieL et al., 2008). There is no previous report of these mites parasitizing T. brasiliensis in Brazil.

This review shows that there is a reasonable number of studies that report the occurrence of mite ectoparasites in T. brasiliensis, however, few have data of large numbers of hosts and parasitic indexes. Moreover, only four studies have data from populations in South America, and the current was the only study conducted in Brazil.

We can consider that are two major gaps in knowledge on mite parasites of T. brasiliensis: diversity related to geographic variation, and temporal and spatial dynamics of populations. Data currently available show that there is great specificity between $T$. brasiliensis and C. robustipes throughout its geographic distribution, and this mite species is highly prevalent and abundant. Both Ewingana species are also present along the geographic distribution of T. brasiliensis, however with much lower prevalence and abundance.

Acknowledgements. We thank the Instituto Chico Mendes de Conservação da Biodiversidade (ICMBio) for the license ( $\mathrm{N}^{\circ}$ 23720-1) for capturing the bats; Núcleo de Reabilitação da Fauna Silvestre e Centro de Triagem de Animais Silvestres da Universidade Federal de Pelotas (NURFS/CETAS/UFPel) for opening the building for the bats capture, and $\mathrm{CNPq}$ and CAPES for financial support.

\section{REFERENCES}

Bradshaw, G. V. R. \& Ross, A. 1961. Ectoparasites of Arizona bats. Journal of the Arizona Academy of Science 1:1-10.

Bush, A. O.; Lafferty, K. D.; Lotz, J. M. \& Shostak, A. W. 1997. Parasitology meets ecology on its owen terms: MARGOLIS Revisted. Journal of Parasitology 83(4):575-583.

Durden, L. A.; Best, T. L.; Wilson, N. \& Hilton, C. D. 1992. Ectoparasitic mites (Acari) of sympatric brazilian free-tailed bats and big brown bats in Alabama. Journal of Medical Entomology 29(3):507-511.

DusBáBeK, F. 1968. Some new genera and species of Myobiidae (Acarina). Folia Parasitologica 15:359-376.

Dusbábek, F. \& Cruz, J. 1966. Nuevos generos y especies de acaros (Acarina: Listrophoridae) parásitos de murciélagos cubanos. Poeyana 31:1-20.

Ezequiel, O. S.; Gazeta, G. S.; Amorim, M. \& Serra-Freire, N. M. 2008. Ácaros da Cheyletidae (Acari:Actinedida) em ecossistema domiciliar no município de Juiz de Fora, Estado de Minas Gerais, Brasil. Revista de Patologia Tropical 37(1):70-74. 
EwING, H. E. 1938. North American mites of the subfamily Myobiinae, new subfamily (Arachnida). Proceedings of the Entomological Society of Washington 40(7):180-197.

FAIN, A. 1994. Adaptation, specificity and host-parasite coevolution in mites (Acari). International Journal for Parasitology 24(8):12731283.

FonSECA, F. 1948. A monograph of the genera and species of Macronyssidae Oudemans, 1936 (synom. Liponissidae Vitzthum, 1931) (Acari). Proceedings of the Zoological Society 118:249-334.

Foster, G. W. \& Mertins, J. W. 1996. Parasitic helminths and arthropods from Brazilian free-tailed bats (Tadarida brasiliensis cynocephala) in Florida. Journal of the Helminthological Society of Washington 63(2):240-245.

FriTz, G. N. 1983. Biology and ecology of bat flies (Diptera: Streblidae) on bats of the genus Carollia. Journal of Medical Entomology 20(1):1-10.

Guzmán-Cornejo, C.; Garcia-Prieto, L.; De Leon, G. P. P. \& MoralesMalacarra, J. B. 2003. Parasites of Tadarida brasiliensis mexicana (Chiroptera:Molossidae) from arid regions of Mexico. Comparative Parasitology 70(1):11-25.

JAMESON, D. K. 1959. A survey of the parasites of five species of bats. The Southwestern Naturalist 4(2):61-65.

KrantZ, G. W. 1978. Manual of Acarology, 2ed., Vol. I and II. Corvallis, Oregon State University Bookstores. 509p.

MAURI, R. 1982. Invasion de viviendas por murcielagos y recuperacion de ácaros ectoparasitos. Neotropica 28:80.

McAllister, C. T.; Bursey, C. R. \& Wilson, N. 2006. Parasites of the Brazilian free-tailed bat, Tadarida brasiliensis, from southwestern Arkansas. Texas Journal of Science 58:87-92.

Muñoz, L.; Aguilero, M. \& Casanueva, M. E. 2003. Prevalencia e intensidad de ectoparasitos asociados a Tadarida brasiliensis (Geoffroy Saint-Hilaire, 1824) (Chiroptera:Molossidae) em Concepcion. Gayana 67(1):1-8.
Muñoz, P.; Fredes, F.; Raffo, E.; GonzÁles-Acuña, D.; Muñoz, L. $\&$ CID, C. 2011. New report of parasite-fauna of the free-tailed bat (Tadarida brasiliensis, Geoffroy, 1824) in Chile. Veterinary Research Communications 35:61-66.

Pence, D. B.; Jones, J. K. \& Knipping, P. A. 1981. Acari of Antillean bats (Chiroptera). Journal of Medical Entomology 18(4):353-354.

Ritzi, C. M.; Ammerman, L. K.; Dixon, M. T. \& Richerson, J. V. 2001. Bat ectoparasites from the Trans-Pecos region of Texas, including notes from Big Bend National Park. Journal of Medical Entomology 38(3):401-404.

SAUNDERS, S. C. 1975. Venezuelan Macronyssidae (Acarina: Mesostigmata). Brigham Young University Science Bulletin Biological 20:75-90. Simmons, N. B. 2005. Order Chiroptera. In: Wilson, D. E. \& ReEDer, D. M. eds. Mammal species of the world: a taxonomic and geographic reference. Baltimore, The Johns Hopkings University Press, p. 312-529.

Spears, R. E.; Durden, L. A. \& Hagan, D. V. 1999. Ectoparasites of free-tailed bats with emphasis on anatomical site preferences for Chiroptonyssus robustipes (Acari: Macronyssidae). Journal of Medical Entomology 36(4):481-485.

Strandtmann, R. W. 1962. Nycterioglyphus bifolium n. sp., a new cavernicolous mite associated with bats (Chiroptera) (Acarina: Macronyssidae). Acarologia 4:623-631.

Whitaker, J. O. \& EAsterla, D. A. 1975. Ectoparasites of bats from Big Bend National Park, Texas. The Southwestern Naturalist 20(2):241-254.

WiLkins, T. K. 1989. Mammalian Species. Tadarida brasiliensis. The American Society of Mammalogists 331:1-10.

YunkeR, C. E. \& Radovsky, F. J. 1966. The Dermanyssidae mites of Panama (Acarina, Dermanyssidae). In: Wenzel, R. I. \& TRIPTON, V. J. eds. Ectoparasites of Panama. Chicago, Field Museum of Natural History, p. 83-103. 